\title{
FROM JUSTICE IN ROBES TO JUSTICE FOR HEDGEHOGS
}

\author{
DE JUSTICIA CON TOGA A JUSTICIA PARA ERIZOS*
}

\author{
Ronald DWORKIN**
}

\section{Resumen:}

En su conferencia magistral dictada en el Instituto de Investigaciones Jurídicas de la Universidad Nacional Autónoma de México, después de recibir el Premio Internacional de Investigación en Derecho Héctor Fix-Zamudio, en la Ciudad de México, el 23 de noviembre de 2006, el autor describe las implicaciones para la filosofia y teoría jurídica de dos fenómenos recientes, los cuales se han convertido en tendencias en la práctica jurídica, y cuestiona una idea estrechamente relacionada con el positivismo jurídico, i.e. el derecho es identificado con un Estado a través de sus soberanos o convenciones, al proponer que el derecho escapa de las fronteras y territorios nacionales.

* Artículo recibido el 1o. de septiembre de 2014 y aceptado para su publicación el 10 de septiembre de 2014.

Lecture delivered at the Instituto de Investigaciones Juridicas of Universidad Nacional Autónoma de México, as recipient of the Premio Internacional de Investigación en Derecho Héctor Fix-Zamudio, Mexico City, 23 November 2006, the ceremony is available: http://www.juridicas.unam. $m x / v j v / v i d e o . h t m ? e=281 \& m=1934 \& p=810$; and the lecture is available: http://www.juridicas. unam. $m x / v j v / v i d e o . h t m ? e=281 \& m=1934 \& p=810 \& p$ $a r=3$ accessed 14 October 2014 [transcription by Martha Linares and revision, including editorial notes, by Imer B. Flores].

** At the time of the Lecture: Frank Henry Sommer Professor of Law and Philosophy at New York University (USA) and Professor of Jurisprudence at University College London (UK) [editor's note]. 


\title{
RONALD DWORKIN
}

\section{Palabras clave:}

Cortes extranjeras, derecho internacional, derechos humanos, ius gentium, jurisdicción universal, Ronald Dworkin.

\begin{abstract}
:
In this Lecture delivered at the Instituto de Investigaciones Juridicas of Universidad Nacional Autónoma de México, after receiving the Premio Internacional de Investigación en Derecho Héctor Fix-Zamudio, in Mexico City, November 23, 2006, the author describes the implications for Legal Theory and Philosophy of two recent phenomena, which have become trends in legal practice, and challenges an idea closely associated with legal positivism, i.e. law is identified with a State through its sovereigns or conventions, by proposing that law escapes from national boundaries and territories.
\end{abstract}

Keywords:

Foreign Courts, International Law, Human Rights, Ius Gentium, Universal Jurisdiction, Ronald Dworkin. 
I want to talk today about legal theory. But I'll start by describing to you two recent phenomena, which I believe are very likely to become trends in legal practice. Just recently, a week or so ago, a prosecutor in Germany issued an indictment against the - then- American Secretary of Defense, Donald Rumsfeld, for violations of human rights: crimes against humanity. ${ }^{1}$ And this is an extraordinary event: a German prosecutor seeking an indictment in Germany for crimes allegedly committed in Washington against the people of Iraq. And this is extraordinary because of the convention that supposes that, as we might put it, law comes in State size bites: law belongs to territories and in general the laws of one country cannot be applied to people and transactions that have nothing to do with that country. As a British lord, in the XIX century with customary British arrogance, once said: "The Queen of Tobago cannot pass a law to bind the world'. ${ }^{2}$ But the German prosecutor thinks he can.

The second development, a little longer standing, is the growing practice of Courts in the United States and, particularly, some justices in the United States' Supreme Court of citing foreign decisions in their opinions. This began to be noticed in a case called Roper case, ${ }^{3}$ which involved the question whether it was constitutional under the United States' Constitution for a State to execute a minor, a twelve year old child, for murder. And in deciding that this was not constitutional, that this violated the United States' Constitution prohibition on cruel and unusual punishment,

1 See Adam Zagorin, 'Exclusive: Charges Sought Against Rumsfeld Over Prison Abuse' Time Magazine (New York 10 November 2006) <http://content.time.com/time/nation/article/0,8599,1557842,00.html> accessed 14 October 2014 [editor's note].

2 The complete reference is 'Can the island of Tobago pass a law to bind the rights of the whole world?' and is attributed to the chief justice, Lord Ellenborough, of the Court of King's Bench, in Buchanan v. Rucker 9 East 192, 102 (K.B. 1808) < http:// harvardmagazine.com/2004/09/chapter-verse.html> accessed 14 October 2014 [editor's note].

3 Roper v. Simmons, 543 U.S. 551 (2005) [editor's note]. 
Justice Kennedy said: I cite as part of my argument decisions in a variety of other States that once had the dead penalty but that did not permit the execution of children. ${ }^{4}$ In a more recent case, Lawrence $v$. Texas ${ }^{5}$ in which the United States Supreme Court decided that States did not have the constitutional authority to make homosexual acts criminal, Justice Kennedy speaking for the Court cited decisions of various other courts, including - and prominently including - a decision of the European Court of $\mathrm{Hu}-$ man Rights in Strasbourg. ${ }^{6}$ And that practice has led to an outcry. Justice Scalia - a very conservative justice of the Supreme Court - said in the dissent that he was outraged by this practice: what does the law of European nations have to do with the United States' constitutional interpretation? The United States is a distinct country with its own law and the decisions of other territories, other nations and international organizations are completely irrelevant. ${ }^{7}$

In the two most recent nomination proceedings in the Senate, confirming President Bush's nominations to the Court, ${ }^{8}$ the nominees -now Chief Justice [John] Roberts and Justice Samuel Alito- were extremely careful to answer no questions. Every time anybody asked a substantial question, they said: We're sorry, because we will be on the

4 Roper (n 3) 575: 'Our determination, finds confirmation in the stark reality that the United States is the only country in the world that continues to give official sanction to the juvenile death penalty' [editor's note].

5 Lawrence $v$. Texas, 539 U.S. 558 (2003) [editor's note].

6 Dudgeon v. United Kingdom, 45 Eur. Ct. H. R. (1981) [editor's note].

7 Lawrence (n 5) 598: 'Constitutional entitlements do not spring into existence because some States choose to lessen or eliminate criminal sanctions on certain behavior. Much less do they spring into existence, as the Court seems to believe, because foreign nations decriminalize conduct' (Scalia dissenting) [editor's note].

8 Since Dworkin's Lecture took place: first, Barack Obama was elected as the 44th President of the United States of America; and, later, the United States' Senate has confirmed the nominations by President Obama of both Sonia Sotomayor and Elena Kagan as Justice of the Supreme Court [editor's note].

\section{PROBLEMA}


FROM JUSTICE IN ROBES TO JUSTICE FOR HEDGEHOGS

Court, as we hope, we would not answer that question. ${ }^{9}$ But when a senator said: What do you think of the practice of citing foreign law in a justification of an American decision? ${ }^{10}$ Both of them said: We reject that practice. We think it is reprehensible. ${ }^{11}$ So this is extremely controversial and, indeed, it's easy to understand why this practice is so controversial. It's one thing to say that a Unites States' Court - Justice Kennedy or Justice Breyer (who has also given to this) - is persuaded by the argument that also persuaded a foreign court. ${ }^{12}$ But that is not what they say. They say it is part of our argument: the very fact that these decisions were made abroad, giving them a kind of authority similar to the authority given to past decisions of United States' Courts. And as I said a moment ago that strikes people as

9 Robert Post \& Reva Siegel, 'Questioning Justice: Law and Politics in Judicial Confirmation Hearings', Yale Law Journal (The Pocket Part), Jan. $2006 \mathrm{http}: / /$ www.thepocketpart.org/2006/01/post_and_siegel.html accessed 14 October 2014: 'Senate confirmation hearings for the Supreme Court nominees have in recent years grown increasingly contentious. Nominees have refused to answer questions about their constitutional views on the ground that any such interrogation would compromise the constitutional Independence of the judiciary' [editor's note].

10 Confirmation hearing on the Nomination of John G. Roberts, Jr. To Be Chief Justice of the Supreme Court of the United States: Hearing Before the S. Comm. On the Judiciary, 109th Cong. 293 (2005) (statement of Sen. Tom Coburn, Member, S. Comm. On the Judiciary): 'Relying on foreign precedent... is that good behavior?' [editor's note].

11 Confirmation hearing on the Nomination of John Glover Roberts, Jr. (n 10) (statement of John Glover Roberts, Jr.): 'not a good approach', and Confirmation hearing on the Nomination of Samuel Anthony Alito, Jr. To Be an Associate Justice of the Supreme Court of the United States: Hearing Before the S. Comm. On the Judiciary, 109th Cong. 471 (2006) (statement of Samuel Anthony Alito, Jr.): 'I don't think that it's appropriate or useful to look to foreign law in interpreting the provisions of our Constitution' [editor's note].

12 Actually, Justices Stephen Breyer and Antonin Scalia held a public debate (American University, Washington College of Law, Jan. 13, 2005) http://www.freerepublic.com/focus/news/1352357/posts accessed 14 October 2014 [editor's note]. 
very odd, because we have become used to the idea that law comes in State size bites.

The most prominent legal philosophical theory of what law is and how you decide what the law is, in the period, I would say, from the beginning of the XIX century to the middle of the XX century, was the philosophy of legal positivism. That philosophy: sponsored the idea that law belongs to distinct States; sponsored the idea that there is something wrong with a judge in Germany passing verdict on events outside and that there is something wrong with United States' justices citing past decisions of other Courts. The nerve of legal positivism has been the claim that morality has nothing to do with the content of the law. You can criticize law on moral grounds. You can hope on moral grounds that law gets enacted. But when the question is: what is the law, right now? Moral arguments have no place, but if moral arguments have no place: how do we decide what the law is? Positivism has given a series of different answers. At the beginning, in the work of Jeremy Bentham ${ }^{13}$ and John Austin, ${ }^{14}$ the answer given was: the authority of a sovereign establishes law. If you want to know what the law is: you look to see what the sovereign head of its political State has said. In the XX century - mid-XX century - a different view emerged, sponsored by Hans Kelsen ${ }^{15}$ and Herbert Hart, ${ }^{16}$ and that view held, not that the sovereign creates law by fiat, but that you find law by consulting the settled practice, the conventions that as-

13 See Jeremy Bentham, An Introduction to the Principles of Morals and Legislation (Jimmy Burns and Herbert Lionel Adolphus Hart eds, first published 1789, Oxford University Press 1996) [editor's note].

14 See John Austin, The Province of Jurisprudence Determined (first published 1832, Hackett Publishing 1998) and The Uses of the Study of Jurisprudence (first published 1863, Hackett Publishing 1998) [editor's note].

15 See Hans Kelsen, General Theory of Law \& State (Harvard University Press 1949) [editor's note].

16 See H.L.A. Hart, The Concept of Law (Oxford University Press 1961) [editor's note].

\section{PROBLEMA}


sociate particular acts of parliaments and judges with the creation of law. Both of these versions of positivism, the oldest sovereign version and the later version that speaks to convention, firmly associate law with particular political communities, with particular States. The sovereign is the sovereign of some place: Mexico, Texas, Argentina, Poland. And the convention -what Hart called the rule of recognition- is a social practice that takes place among the officials and lawyers of particular political communities. Hart said: There is a rule of recognition of Great Britain. ${ }^{17}$ Some people have supposed that there is such a thing as international law, but that governs the relations among States in any ways that on a positivist test it is a rather dubious candidate for law.

The connection between legal positivism, as a nascent and then dominant theory of law, and what I'm calling the automatic association of law with political community was dramatically illustrated - and I'm afraid that once again I'm going to call upon American examples - in the development in the early XIX century of the idea of Federal Common Law within the United States. As you know in the United States we have on most issues laws of separate states: Rhode Island has one law, Wisconsin another. And in the early part of the XIX century, the idea developed that Federal Courts -National Courts - were bound by the laws of the separate States, but they could ask what were the principles common to the various States. They could create as they said a Federal Common Law: so that citizens suing in any place, in the Federal Court system, whether in Wisconsin or Rhode Island, would be governed by the same principles. ${ }^{18}$ The great jurist Oliver Wendell Holmes Jr., a firm legal positivist, denounced that idea in a series of writings. He said, at one point law is not a brooding omnipresence in the sky', law is the creation of particular sovereigns and in this

17 Hart (n 16) 104: 'what the Queen in Parliament enacts is law' [editor's note].

18 Swift $v$. Tyson 41 U.S. 1 (1842) [editor's note]. 
case of particular States. ${ }^{19}$ And in a famous case, called the Taxi $\mathrm{Cab}$ case, ${ }^{20}$ he dissented from the practice of Federal Common Law and he did so on legal positivist grounds. A few years later, in one of the most famous cases, famous decisions of the Supreme Court, called Erie Railroad Co. $v$. Tompkins, ${ }^{21}$ the Supreme Court announced that it was changing its practice: it discarded the idea of Federal Common Law. And in legal opinions, in a series of judicial opinions, which I believe mark the high point of legal positivism as a theory of law, it abolished Federal Common Law, and said: Federal Courts sitting in the State of Wisconsin must apply Wisconsin law because that's the only sovereign. ${ }^{22}$ Once again a triumph for the idea that law belongs to particular communities and there is no such thing - to paraphrase Oliver Wendell Holmes Jr. - as 'law in the air'. And, yet, the two developments that I began by describing both seem to contradict that idea they seem to think that law has a presence over and above the location of law in particular political communities.

Now, as many of you know, legal positivism is no longer an ascending - certainly not in academic law and even more certainly not in legal practice- influential theory of law. It survives as a working influence on judges in the United States only as the creed of the very right wing conservative judges on the Supreme Court. In the form of what

19 The complete reference is "The common law is not a brooding omnipresence in the sky, but the articulate voice of some sovereign or quasi sovereign that can be identified.' Southern Pacific Company v. Jensen, 244 U.S. 205, 222 (1917) (Holmes dissenting) [editor's note].

20 Black and White Taxicab and Transfer Company v. Brown and Yellow Taxicab and Transfer Company, 276 U. S. 518 (1928) [editor's note].

${ }_{21}$ Erie Railroad Co. v. Tompkins, 304 U.S. 64 (1938) [editor's note].

22 Erie Railroad Co. (n 21) 78: 'Except in matters governed by the Federal Constitution or by Acts of Congress, the law to be applied in any case is the law of the State. And whether the law of the State shall be declared by its Legislature in a statute or by its highest court in a decision is not a matter of federal concern. There is $\mathrm{n}$ federal general common law' [editor's note]. 
they call 'originalism', ${ }^{23}$ that is that the Constitution should be interpreted in accordance with the intentions of the XVIII century gentlemen who enacted it. The judges, who announce their dedication to this form of positivism, the conservative members of the Supreme Court, only paid lip-service to it, however, in the famous case of Bush $v$. Gore, ${ }^{24}$ a case that I believe you've heard something over in recent weeks in this country. ${ }^{25}$ The right wing judges abandoned all their dedication to legal positivism.

Legal positivism has been in decline, I believe, for two reasons: First, because the motive for legal positivism, originally, was moral skepticism. Positivism was an attempt to rescue law from the general assumption, which began in the larger intellectual movements of positivism in Europe in the XIX century - and to some degree at the end of the XVIII century - as an attempt to show that law - contrary to early ideas about natural law - could be understood free from morality and, therefore, free from the suspicion largely growing among the scientist of the time that there was no such thing as objective moral truth. And among philosophers, analytic philosophers, that idea is no longer -anyway, is near not- so prominent as it was. As it also turned out the methodology of legal positivism has -in a waycollapsed. Legal positivism was first defended by Austin -and to some extent by Bentham and others - as a theory about the very meaning of law or the very concept of law.

23 See, for example, Robert Heron Bork, The Tempting of America. The Political Seduction of the Law (The Free Press 1990); and Antonin Scalia, 'Common Law Courts in a Civil-Law System: The Role of United States Federal Courts in Interpreting the Constitution and the Laws' in A Matter of Interpretation. Federal Courts and the Law (Amy Gutmann ed, Princeton University Press 1997), 3-47. See also Ronald Dworkin 'Comment', in ibid, 115-127, and Antonin Scalia 'Response', in ibid, 129, 144-149 [editor's note].

24 Bush v. Gore, 531 U.S. 98 (2000). See Ronald Dworkin (ed), A Badly Flawed Election (The New Press 2002) [editor's note].

25 In a clear allusion to the parallels with the judicial decision regarding the Mexican Presidential Election of 2006 [editor's note]. 
And can no longer be defended in that way and it no longer captions either the phenomenology of actual judicial practice - or it seems to me the record of actual judicial practice. So, in recent decades, an attempt has been made to create an alternate account of the content of law, an alternate answer to the question: how do we identify which legal propositions are true and which not? If a legal proposition - some claim about what the law requires or permits - is true: what makes it true? My own answer to that question has been to describe legal reasoning not as an attempt to retrieve from the past some authoritative declaration of a sovereign or to identify some convention that give us some institution's authority, but rather to understand law as an interpretive practice. So the question what is the law on this subject, requires those who would answer it -citizens, law professors, law students, and judges - to look at the record of what the law has been and attempt to interpret that record to make sense of that record by asking what principles would justify that record and then to extend those principles into the future.

Imer Flores suggested the title of today's lecture and I am very grateful for his suggestion. He called the lecture, when I described to him what I planned to do, as 'From Justice in Robes to Justice for Hedgehogs' and that describes two books, titles of two books, one I have written and one I am trying - as hard as I can- to write: the past and the future. ${ }^{26}$ But the titles are meant to convey this, that we understand law, that we understand the role that justice plays in law, only when we understand law not in isolation from the rest of human value, but as part of a largest scheme of justice, using Isaiah Berlin's idea: justice for hedgehogs, not for foxes. ${ }^{27}$ And it's part of my argument that interpreta-

26 Ronald Dworkin, Justice in Robes (Harvard University Press 2006), and Justice for Hedgehogs (Harvard University Press 2011) [editor's note].

27 Isaiah Berlin (quoting Archilochus), 'The Hedgehog and the Fox', in Isaiah Berlin, The Proper Study of Mankind. An Anthology of Essays (Henry Hardy and Roger Hausheer eds, Farrar, Straus and Giroux 1998) 
tion is, as it dominates in my view legal reasoning, a distinct kind of intellectual activity but also has its presence across the whole domain of interpretation. So then if we want to understand interpretation as a legal activity, we have to think about artistic interpretation, historical interpretation, biblical hermeneutics, literary study. And my argument in Justice for Hedgehogs - if I ever finish it - is that we understand interpretation as a distinct intellectual activity by accepting that in interpretation, across all these domains, the purpose of the activity is part of the test of truth. So that if we ask ourselves what is the right way to read a poem or the right way to direct a performance of a Shakespearean play we have to begin with the question: why are we engaged in interpretation? Anyway, what justifies the enterprise of interpretation? In the case of artistic interpretation, the answer must be: some theory about the character and value of aesthetic experience. In the case of law, it must be something about politics and the suggestion that I have made is: we interpret as part of legal reasoning. Precedent is important, the past is important, because in law integrity is important. And by integrity I mean the coherence of the set of principles that we deploy to justify coercive action, that when political power is used against individuals to coerce them we need - or those who exercise the power need-a justification. And that justification must be the same justification as cited and used for other people, that in matters of principle those who exercise power must speak with one voice. And that is why I think that legal reasoning should be understood as interpretive, as attempting at all times to identify the principal base of the law as it stands. So that principal base can be extended into the new issues that confront lawyers, citizens, and judges, day by day.

Now, until very recently, until I began to think about such phenomenon, as those I described at the beginning of

436: 'The fox knows many things, but the hedgehog knows one big thing' [editor's note]. 
these remarks, I too assumed that the upshot of this method of interpretation, this concentration on integrity, would produce law in State size bites, because coercion is exercised by States. And the questions of legitimacy that arise are questions about the legitimacy of particular political organizations. And so I've had said in Law's Empire ${ }^{28}$ -and in almost everything I've written about law- we demand integrity across the law of a political community and in that way I have joined in the positivist assumption that law is the law of a particular place. I have elsewhere rejected the idea of a common law across political communities, but the difference between positivism and the way in which positivism demands identification of law with States and the consequence of an interpretive view of law is this: the connection that positivism establishes is conceptual, it claims that the very meaning of law ties law to States either through sovereigns or through conventions. ${ }^{29}$ And the interpretive approach rests finally on a moral claim about the purpose and value of integrity. And I now want to suggest, as I believe I am beginning myself to see, that there are very powerful arguments that integrity as a virtue, as a demand, escapes national boundaries. ${ }^{30}$

28 See Ronald Dworkin, Law's Empire (Harvard University Press 1986) [editor's note].

29 Dworkin (n 28) 102: 'Interpretive theories are by their nature addressed to a particular legal culture, generally the culture to which their authors belong... The very detailed and concrete legal theories lawyers and judges construct for a particular jurisdiction, which extend into the detail of its adjudicative practice, are of course very much tied to that jurisdiction. The more abstract conceptions of law that philosophers build are not. It would be suspicious, even alarming, if conventionalism, for example, were said to be the most successful general interpretation of Rhode Island law but not of the law of Massachusetts or Britain in the same period. But there is no reason to expect even a very abstract conception to fit foreign legal systems developed in and reflecting political ideologies of a sharply different character' [editor's note].

30 See Ronald Dworkin, 'A New Philosophy of International Law' (2013) 41 Philosophy \& Public Affairs 1 [editor's note]. 
Now, it is at this point, in this remarks that I want to introduce the idea of the international community. The international community so far exists largely in rhetoric. We hear and read that the international community approves of certain action, disapproves of other action. The international community took a stand in the Balkans, failed in Rwanda. These are very common phrases. And I now suggest that we take them seriously and try to decide what the international community, as used in such ideas, means. It is also used - and this is particularly important-critically. I think is fair to say, as people commonly do, that whatever it is, the international community approved of the United States' action in Afghanistan, but strongly disapproved of the United States' action in Iraq. Another way to put it is: the United States acted with the sanction of the international community in Afghanistan, but against the will of the international community in Iraq, with —as it turned outdisastrous consequences.

What is this international community? It is an old idea. The Romans had the idea they called ius gentium: of a law that was - this is a quite interesting comparison- to be applied to foreigners in Roman courts. Roman courts were not allowed to apply Roman laws to aliens that happen to be in Rome. So the idea developed that, among other territories, chiefly in the Italian peninsula, in northern Italy, the common law, the law common to other jurisdictions, should be applied, the so-called ius gentium. Ius gentium was then a phrase used in other ways and became a source through Grotius and others of what we now think of as international law, ${ }^{31}$ but it started with a sense not of a law governing nations but of a law governing people that nevertheless did not draw its authority from the institutions of any particular political community. The idea has been used in many other ways: the Declaration of Independence, that which we recite to ourselves every fourth of July states in Thomas

31 See Hugo Grotius, On the Law of War and Peace (Stephen C. Neff ed, Cambridge University Press 2012) [editor's note]. 
Jefferson's wonderful words that when a nation embarks on a course of revolution - as United States did- it owes a decent respect for the opinions of mankind, ${ }^{32}$ something that my government has not been conspicuously enthusiastic about in recent years. But it wasn't, I think, until very recently, certainly not until after the Second World War, that the idea of the international community as a source of legitimacy began. The international community is closely related to international organizations in particular the United Nations, but it is not the same as the United Nations. A decision of the United Nations is very strong evidence of what the international community believes and approves or disapproves, but it is not necessary or sufficient if the international community fails to achieve warrant for intervention because one nation of the security council, say China, has vetoed the resolution that will not destroy the claim that the international community approves or disapproves of something. This is still at the level of rhetoric. It's not necessary and I don't believe it is sufficient. I believe that there might be decisions of the United Nations, which did not express the will of the international community. If -as I am now suggesting to you - the international community is not a juridical person, it's not a legal entity of some kind, even in the way the United Nations is, then what is it?

I think we can approach this question by asking two others: what is the domain of the international community's authority? And, who are members of the international community? It - the international community - does not include every political community in the world. If it did, there

32 Thomas Jefferson, 'The Declaration of Independence' in The Political Writings of Thomas Jefferson (Edward Dumbaud ed, The Liberal Arts Press, 1955) 3: 'When in the Course of human events it becomes necessary for one people to dissolve the political hands which have connected them with another, and to assume among the powers of the earth, the separate and equal station to which the Laws of Nature and of Nature's God entitle them, a decent respect to the opinions of mankind requires that they should declare the causes which impel them to the separation' [editor's note].

\section{PROBLEMA}


could be no such thing as the common law of the international community. The international community could not be thought to have a common law of everything. The Mexican congress has no business adopting zoning regulations for the city of London. I think the key to the answer to both of the questions - what is the domain of the international community and who is on it - must lay in the idea of human rights. The international community speaks, warrants, approves, disapproves, on the ground of human rights. It authorizes or approves of intervention only on support of human rights and the nations that make up the international community are those that accept the broad idea of human rights. That broad idea is a contested idea. We need if we are going to explore the idea that I'm now trying to begin, which is: integrity is a demand of the international community in the field of human rights. If we are now beginning to explore that we need an account - and a rather abstract account - of human rights. I've tried to give that account -in a way that I believe will serve the present purpose - in a recent book called Is Democracy Possible Here?33 And I simply summarize the main points of my account of human rights. I believe that the principle of human rights, the main principle, is not a list of distinct human rights but is rather an attitude that government, any government or any collection of power, must show to those at the cutting edge of that power. And the principles that compose human rights, the most abstract stated of these: every human being, every human creature, with a life to lead, has a valuable life, valuable in the sense that it matters and matters objectively and matters equally whether that life succeeds or fails. Every human being is a locus of value and the inherit value of every human being is equal. That's the first of the two ideas, which I believe form the idea of human rights. The second is this. In spite of the fact that every human being is the locus of value and that is objectively im-

33 Ronald Dworkin, Is Democracy Possible Here? Principles for a New Political Debate (Princeton University Press 2006) [editor's note]. 
portant that that life realize its value, one person must be given prime and exclusive responsibility for the success of that life and that is the person whose life it is. These are two principles - the first a principle of equality, the second a principle of liberty - that we must respect jointly in any theory of human rights. And my suggestion to you this morning is that we should deem, as members of the international community, that we take to be a kind of legal person, those nations that accept those two principles, not necessarily without exception and not necessarily all agreeing on what these principles require on particular circumstances. But we know of nations that do not qualify: Nations that endorse genocide, that subordinate woman, that do not tolerate a free press. These are nations which we cannot regard as members of the international community. Once we accept that it is the burden of the international community to respect human rights everywhere. And that answers our questions: that is the international community and the domain of the international common law. The domain within which we must demand integrity of the international community is the same domain: the domain of insisting on these principles and an attempting collectively to work out what they require.

If we accept to this idea, then law breaks loose, at least in this particular, of the State boundaries, because we've identify a point of integrity in coercion, which escapes the boundaries of particular political communities. It isn't international law, in the traditional sense of the law of States, the law governing the relations between States. It is international law in a different sense: it's that body of law as to which all the members of the international community have a responsibility to attempt collectively to speak with one voice on matters of human rights because that is what the basic principle of integrity requires. And if we expand the idea of integrity to match the fact that coercive force is now in the hands of an international community then we must expand what integrity requires. When Germany considers 
the case of Criminal Complaint Against Donald Rumsfeld et al. for war crimes in Iraq, perhaps elsewhere, then it must consider the following question: if there is an international community and if integrity across the range of that community is in fact a demand of legitimacy, then no nation can have the power to exonerate its own citizens from the demands. ${ }^{34}$ We are used to the idea, again, an ancient idea, that States can exercise universal jurisdiction over pirates and over hijackers. And, now, we add, States qua members of the international community can exercise universal jurisdiction over those who are accused of war crimes. This idea was fraught with danger and it will take another lecture to work out the details but I'm now simply trying to show how legal theory can set the stage for that further discussion.

And now about the citation of foreign law in domestic courts: if integrity is a demand of the international community, then of course the United States' Supreme Court when faced with questions, which though questions of American constitutional law are also questions about basic human rights, then it must cite and pay attention to the decisions of other members of the international community who've tried to answer that questions. Not as is often said, because it should listen to the arguments that other nations have said, not because this is binding as a matter of the laws of precedent, but simply because if law is a matter of interpretation, the data that an American court must interpret in search of integrity explodes beyond American law, it must include the data of all members of the international community so far as they are attempting to achieve integrity in the character of the human rights they collectively enforce.

I would not try to summarize this argument. It wandered a bit. But I do want to leave you as I end with a further suggestion. The occasion: this wonderful medal with this

34 At the end, the Prosecutor General at the Federal Supreme Court in April 5, 2007, decided to dismiss the case http://ccrjustice.org/ourcases/ current-cases/german-war-crimes-complaint-against-donald-rumsfeld-etal accessed 14 October 2014 [editor's note]. 
beautiful ribbon, the presence of the wonderful teacher, in whose name this medal is stroked and given. This is an occasion in which we think about the importance of jurisprudence, our subject, and we have to think about the importance of legal theory. We remind ourselves that law is more than power and strategy, that law is power and strategy disciplined by principle. And when we accept that that principle is not something distinct, some arcane legal principle; that that principle is moral principle, that law simply doesn't interact with morality, but the law is part of morality. Then we see that legal theory, jurisprudence, whose vision is to explore the principles that discipline law also add to law's power to face what will increasingly be a more interconnected world.

\section{BIBLIOGRAPHY}

Austin J, The Province of Jurisprudence Determined (first published 1832, Hackett Publishing 1998).

- The Uses of the Study of Jurisprudence (first published 1863, Hackett Publishing 1998).

Bentham J, An Introduction to the Principles of Morals and Legislation (Jimmy Burns and H L A Hart (eds), first published 1789, Oxford University Press 1996).

Berlin, I (quoting Archilochus), 'The Hedgehog and the Fox', in Isaiah Berlin, The Proper Study of Mankind. An Anthology of Essays (Henry Hardy and Roger Hausheer eds, Farrar, Straus and Giroux 1998).

Bork RH, The Tempting of America. The Political Seduction of the Law (The Free Press 1990).

Breyer, Stephen and Scalia, Antonin, held a public debate (American University, Washington College of Law, Jan. 13, 2005) http://www.freerepublic.com/focus/ news/1352357/posts accessed 14 October 2014. 
Dworkin R (ed.), A Badly Flawed Election (The New Press 2002).

- Justice in Robes (Harvard University Press 2006).

- Justice for Hedgehogs (Harvard University Press 2011).

— Law's Empire (Harvard University Press 1986).

- 'A New Philosophy of International Law' (2013) 41 Philosophy \& Public Affairs 1.

- Is Democracy Possible Here? Principles for a New Political Debate (Princeton University Press 2006).

Grotius, H, On the Law of War and Peace (Stephen C. Neff ed, Cambridge University Press 2012).

Hart HLA, The Concept of Law (Oxford University Press 1961).

Jefferson, T, 'The Declaration of Independence' in The Political Writings of Thomas Jefferson (Edward Dumbaud ed, The Liberal Arts Press, 1955) 3.

Kelsen, H, General Theory of Law \& State (Harvard University Press 1949).

Lord Ellenborough, of the Court of King's Bench, in Buchanan $v$. Rucker 9 East 192, 102 (K.B. 1808) http:// harvardmagazine.com/2004/09/chapter-verse.html accessed 14 October 2014.

Post, Robert \& Siegel, Reva, 'Questioning Justice: Law and Politics in Judicial Confirmation Hearings', Yale Law Journal (The Pocket Part), Jan. 2006 http://www.thepocketpart.org/2006/01/post_and_siegel.html accessed 14 October 2014.

Scalia, A, 'Common Law Courts in a Civil-Law System: The Role of United States Federal Courts in Interpreting the Constitution and the Laws' in A Matter of Interpretation. Federal Courts and the Law (Amy Gutmann ed, Princeton University Press 1997). 
Zagorin, Adam, 'Exclusive: Charges Sought Against Rumsfeld Over Prison Abuse' Time Magazine (New York 10 November 2006) http://content.time.com/time/nation/article/0,8599,1557842,00.html accessed 14 October 2014.

Swift $v$. Tyson 41 U.S. 1 (1842).

Southern Pacific Company v. Jensen, 244 U.S. 205, 222 (1917).

Transfer Company, 276 U. S. 518 (1928).

Railroad Co. v. Tompkins, 304 U.S. 64 (1938).

Dudgeon v. United Kingdom, 45 Eur. Ct. H. R. (1981).

Bush v. Gore, 531 U.S. 98 (2000).

Lawrence v. Texas, 539 U.S. 558 (2003).

Roper $v$. Simmons, 543 U.S. 551 (2005).

Black and White Taxicab and Transfer Company v. Brown and Yellow Taxicab and Erie. 